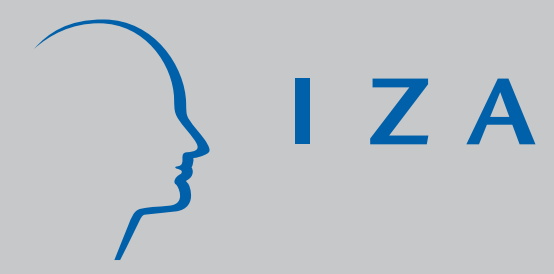

IZADP No. 4142

Temporary Labour Migration and Welfare at the New European Fringe:

A Comparison of Five Eastern European Countries

Alexander M. Danzer

Barbara Dietz

April 2009 


\title{
Temporary Labour Migration and Welfare at the New European Fringe: A Comparison of Five Eastern European Countries
}

\author{
Alexander M. Danzer \\ Royal Holloway, University of London \\ and IZA \\ Barbara Dietz \\ Osteuropa-Institut Regensburg \\ and IZA \\ Discussion Paper No. 4142 \\ April 2009 \\ IZA \\ P.O. Box 7240 \\ 53072 Bonn \\ Germany \\ Phone: +49-228-3894-0 \\ Fax: +49-228-3894-180 \\ E-mail: iza@iza.org
}

Any opinions expressed here are those of the author(s) and not those of IZA. Research published in this series may include views on policy, but the institute itself takes no institutional policy positions.

The Institute for the Study of Labor (IZA) in Bonn is a local and virtual international research center and a place of communication between science, politics and business. IZA is an independent nonprofit organization supported by Deutsche Post Foundation. The center is associated with the University of Bonn and offers a stimulating research environment through its international network, workshops and conferences, data service, project support, research visits and doctoral program. IZA engages in (i) original and internationally competitive research in all fields of labor economics, (ii) development of policy concepts, and (iii) dissemination of research results and concepts to the interested public.

IZA Discussion Papers often represent preliminary work and are circulated to encourage discussion. Citation of such a paper should account for its provisional character. A revised version may be available directly from the author. 


\begin{abstract}
Temporary Labour Migration and Welfare at the New European Fringe: A Comparison of Five Eastern European Countries ${ }^{*}$

This paper investigates patterns and determinants of temporary labour migration in Armenia, Belarus, Georgia, Moldova and Ukraine after EU enlargement in 2004. Migration incidence, destination choices and migration determinants differ between poorer and better-off countries. Although broadly in line with general results from the migration literature, we observe some peculiarities like the high share of older migrants and a modest role of family obligations in the migration decision process. We find no indication of a brain drain related to temporary migration in sending regions as the educational background of migrants is rather low. Migration is used as household insurance against unemployment and is associated with lower incidence of poverty. This finding remains robust when attempting to reduce the potential omitted variable bias with an instrumental variable approach.
\end{abstract}

JEL Classification: F22, J61, I31, P23

Keywords: temporary migration, welfare, Eastern Europe, cross-country study

Corresponding author:

Barbara Dietz

Osteuropa-Institut Regensburg

Landshuter Str. 4

93047 Regensburg

Germany

E-mail: dietz@osteuropa-institut.de

\footnotetext{
* We would like to thank Sule Akkoyunlu, Richard Frensch, Francis Vella as well as seminar participants at the $5^{\text {th }}$ IZA Migration Meeting Bonn, the ESPE conference London, the SMYE Lille and the R28 conference Florence for helpful comments on earlier drafts of this paper. Furthermore the authors would like to acknowledge the sponsorship of the European Commission INTAS scheme Grant no. 04-79-7165.
} 


\section{Introduction}

Economic migration from countries of the Commonwealth of Independent States (CIS) to the European Union (EU) have considerably increased in recent years. Nevertheless, there is only little sound research on the quantity, destinations and determinants of these movements. Official statistics on the outflow of people from former Soviet Union countries are typically scarce and sometimes misleading ${ }^{2}$, while individual data on the base of survey results are limited to singlecountry studies. An assessment of economic migration in this region is exacerbated by the fact that a great part of these movements is temporary and irregular.

This paper takes advantage of a unique cross-country survey on recent migration movements which has been conducted with comparable survey methodology in Armenia, Belarus, Georgia, Moldova and Ukraine. It is the first thorough analysis of migration patterns in this post-Soviet region. Because interviews were conducted in the sending countries, the data cover persons who have returned after migrating abroad for a certain period of time, i.e. temporary migrants. The strength of the survey is the inclusion of irregular migrants, as migrants were interviewed independent of whether they legally crossed the border and found a job in the receiving country. Using the results of this comprehensive survey, we analyse patterns and determinants of temporary movements in the Eastern European borderlands of the enlarged EU as well as the impact of migration on household welfare. It is of particular concern for this research to investigate whether standard results from the migration literature can be identified in the post-Soviet context.

Our main findings are the following: Across sending countries, temporary migration incidence differs considerably. While Moldova faced a high temporary labour emigration since 2004, Armenia, Belarus and Ukraine were confronted with a more moderate outflow. To the contrast, temporary labour movements from Georgia were quite low. With respect to destination regions, Russia and other CIS countries attracted the majority of temporary migrants from Armenia, Belarus, Moldova and Ukraine, while Georgian labour migrants headed predominantly for European and overseas destinations. Migration determinants are broadly in line with expectations from the economic migration literature in low income countries. However, we disentangle some peculiarities such as a back-loaded inverse U-shaped association between age and migration propensity, a negative impact of university education and a rather low influence of family obligations on migration decisions. Migration is a household strategy to overcome unemployment, however, households in the poorest regions cannot afford this insurance tool. Generally, we find a

\footnotetext{
${ }^{2}$ Some country statistics only consider migrants who de-register officially, other sources like the United Nations Population Division data base use nationality based definitions of stocks of migrants which are inappropriate to investigate migration flows.
} 
negative association of migration and current poverty. Although our choices are limited, we apply several tests to show that the poverty reducing effect of migration is not merely driven by reverse causation.

The remainder of the paper is structured as follows: In Section 2 we give the aim and motivation for the study of migration determinants in the Eastern European borderlands. Section 3 provides an overview of the five countries under consideration which have made some similar transition experiences but also differ especially in economic development and the political sphere. While Section 4 presents the conceptual approach to model the determinants of temporary migration decisions, Section 5 introduces the new survey data set. In Section 6 a descriptive analysis of migration patterns across countries is given. Section 7 illustrates the methodology, the econometric approach and the estimation results of migration determinants. This allows us to conclude in Section 8 with some relevant policy implications for both, migrant sending and receiving countries.

\section{Aim and motivation}

With the political and economic transformation in Eastern Europe following the break-up of the Soviet Union, regional and international emigration barriers collapsed allowing an increasing number of people to leave their home countries temporarily or permanently. The destinations of these migrations varied widely: successor states of the Soviet Union were addressed as well as European countries and other destinations in the Western world such as the USA, Canada or Israel. The vast array of migration types ranged from ethnically motivated movements to temporary labour migration. While ethnic return migration prevailed in the aftermath of the dissolution of the Soviet Union, labour migration was increasingly observed across the region in recent years (IOM 2005, Mansoor and Quillin 2006).

The EU enlargement in 2004 established a new dividing line in Eastern Europe, separating the successor states of the Soviet Union from their former Central European allies, which now belonged to the European Union. ${ }^{3}$ Because of living standard differentials, old and new European Union member states became targets of an increasing migration pressure from CIS countries either directly bordering the enlarged EU (Moldova, Ukraine, Belarus) or being close to its borders (Armenia, Georgia). As EU countries provided little space for the legal admission of labour

\footnotetext{
${ }^{3}$ To cross the border towards EU countries, citizens from post-Soviet states required a travel visa since 2003, a costly and time consuming obligation.
} 
migrants from CIS countries, temporary and irregular movements became widespread (IOM 2005, IOM 2008).

Inside the European Union, the reaction towards an increasing migration from the new Eastern borderlands countries was mixed. Whereas the introduction of a regulated temporary labour migration scheme from non-member states has recently been debated in the light of aging societies and the skill mismatch in labour markets (Brücker 2007, Hönekopp and Mattila 2008), there exists an unmistakable political and societal opposition against new labour movements from the East. In sending regions, labour emigrations were seen with both social concerns and economic hopes. While the outflow of skilled and young people was opposed because of a potential brain and youth drain, the receipt of remittances was considered rewarding for the respective economies (Krieger 2004, Danzer and Handrich 2007).

Against the background of new migration challenges in the post-Soviet space, this paper compares patterns of temporary labour movements and explores their determinants in five successor states of the USSR, i.e. Armenia, Belarus, Georgia, Moldova and Ukraine. Furthermore, we explore the poverty reducing effect of migration and address the problem of endogenous migration choice. It is the aim of this study to provide novel insights into the factors that characterize and shape temporary migration movements in the region after the enlargement of the European Union.

\section{Countries under consideration: stylized facts}

The countries of our study_Armenia, Belarus, Georgia, Moldova, and Ukraine—-were all part of the Soviet Union, thus sharing common economic and political experiences and common transition challenges after the break-up of the Soviet Union. Although all of these countries went through specific migration episodes after becoming independent, some common patterns exist. Since the collapse of the Soviet Union triggered the return of ethnic sub-populations to their (former) ethnonational homelands, migrations in the initial post-Soviet era were predominantly of an ethnic character (Brubaker 1998). While ethnic Russians who had lived in Armenia, Belarus, Moldova or Ukraine moved back to the Russian Federation, Armenians, Belarussians, Moldavians or Ukrainians who had settled (or were forced to settle) in other Soviet Union republics returned to their newly independent nation states (Ivakhnyuk 2006). These return movements were partly supported by the political uncertainty involved in the establishment of new nation states ${ }^{4}$ and a number of post-Soviet states also experienced considerable emigrations because of ethno-political

\footnotetext{
${ }^{4}$ People of a minority nationality often turned home even when being born outside their titular country.
} 
conflicts and ecological catastrophes. In Georgia for example political unrest and ethnic clashes in South Ossetia and Abkhazia triggered huge emigrations. The 1988 earth quake in Armenia resulted in an outflow of citizens, while ethnic tensions with the Azerbaijani minority forced many Azerbaijani to leave Armenia (Yeganyan 2006). The majority of movements in the post Soviet period were directed towards neighbouring states formerly belonging to the USSR. Between 1990 and 2006 approximately 80\% of emigrants from former Soviet Union countries moved within the CIS region, predominantly towards Russia (Mansoor and Quillin 2006: 3).

According to official data Ukraine, Moldova, Armenia and Georgia experienced remarkable net emigrations between 1991 and 2006 (see Figure 1). ${ }^{5}$ Migration losses in this period ranged from $1.2 \%$ of the population (561 thousand people) in Ukraine to $23 \%$ of the population (1 million people) in Georgia. To the contrast, net immigration prevailed in Belarus, most likely reflecting the comparatively stable economic situation and a politically rather closed country.

Overall, official migration data indicate a decrease of migration activities in the new East European borderlands since the middle of the 1990ies, pointing to progressing ethnic unmixing within the CIS countries. In this period, migration movements in the region underwent two remarkable changes: economically motivated movements gained in weight and the share of people leaving for Western destinations increased (Mansoor and Quillin 2006:5, Malynovska 2006). While the USA, Germany and Israel had been the most important Western destinations in the initial migration period after the collapse of the Soviet Union, the recent destination choice expanded to an increasing number of Western countries and among them countries like Italy and Spain, which had little immigration experience before the 1990s.

Despite the fact that net migrations in the five countries followed a decreasing trend since the end of the 1990ies when referring to official data (Figure 1), empirical observations point to the fact, that Russia as well as a number of European Union states faced an increasing (temporary) labour immigration from Ukraine, Moldova and Georgia during that period (OECD 2006: 384-394). This inconsistency is due to the fact that only persons who receive an official permission to reside abroad (Ukraine) or those who dispense their residence permits (Moldova, Georgia) are officially registered as emigrants in these states. Citizens of post-Soviet countries who leave on the base of family visits and tourist visa, who participate in bilateral agreements for temporary work or in a student exchange program are not counted in official emigration statistics. Besides, illegal border crossing or visa overstaying add to an increasing number of citizens from post-Soviet states, who live and work abroad. In the early 2000s, between 3.5 and 4.2 million legal and illegal migrant

\footnotetext{
${ }^{5}$ It has to be noted that the quality of official data can be questioned at least in the early years after the break-down of the FSU.
} 
workers were estimated to have temporarily left Armenia, Georgia, Moldova and Ukraine, 60\% of them with the destination Russia (Ivakhnyuk 2006).

In the light of economic reasoning, the growing economic migration in the new European borderlands should reflect disparities in income, wealth and quality of life between sending and receiving regions. Indeed, substantial differences in living standards can be observed when comparing the GDP per capita in Belarus, Ukraine, Moldova, Georgia and Armenia with corresponding data from Russia and a selection of EU countries (Table 1). Furthermore, the human development index (HDI), which portrays a country's average achievements in three basic aspects of human development (health, knowledge, and a decent standard of living) demonstrates a noticeably higher HDI rank of European Union members as compared to Belarus, Ukraine, Armenia, Georgia and Moldova (Table 2). Although Russia is ahead of Armenia, Georgia, Moldova and Ukraine in terms of HDI, it ranks below Belarus. Despite a certain economic recovery in recent years, poverty is still widespread in the countries under consideration. In Armenia, the share of the population living in poverty, i.e. below US\$2 per person and day, amounted to $31.1 \%$, in Georgia to $25.3 \%$ and in Moldova to $29.1 \%$. To the contrast, only $4.9 \%$ of the population in Ukraine were poor according to this definition, and less than $2 \%$ of the population experienced poverty in Belarus (EBRD 2007). ${ }^{6}$

Next to economic disparities that support the growing dynamics of economically motivated migration in the European borderlands, former contacts within the Warsaw pact, ethnic affiliations across borders, linguistic ties with Russia and specific migration traditions in connection with former ethnic return movements, are of relevance. All countries under consideration here were structurally interwoven with Russia in Soviet times - through ethnic minority relations as well as through a common educational system, a common military service and a governmentally regulated labour allocation across Union Republics. However, the recent foreign relations to Russia were characterized by a number of severe conflicts, particularly in the case of Georgia and Ukraine.

\footnotetext{
${ }^{6}$ The poverty headcount ratio is defined according to the World Bank definition by the share of the population living on less than US\$2 per person and day (in 1993 US\$ at purchasing power parity). The data refer to 2002 (Belarus), 2003 (Armenia, Georgia, Ukraine) and 2005 (Moldova).
} 


\section{Determinants of temporary migration movements: conceptual approach}

One of the most influential theoretical approaches to explain the determinants of individual migration decisions relates to cost-benefit considerations in the framework of neoclassical economics (Sjaastad 1962, Harris and Todaro 1970). ${ }^{7}$ In line with this concept, people move permanently if the discounted value of expected lifetime earnings - reduced by migration related expenditures - is bigger in the destination than in the home country. On the side of migration costs, all kinds of expenses associated with moving abroad have to be taken into account including psychological costs of leaving family and friends behind. Within this permanent migration framework, temporary labour movements would only occur if the migration decision turns out to be a failure, i.e. expectations with respect to future net benefits do not materialize (Duleep 1994, Cassarino 2004).

An increasing body of literature has challenged the concept of lifetime income maximizing individuals as drivers of labour movements, particularly in a context where migration barriers and market failures exist (Stark 1991, Taylor 1996). The most prominent strand of this literature, the new economics of labour migration argued that migration decisions are predominantly made by families, not by individuals. Market failures (e.g. in insurance markets) and economic shocks at home are seen as initial push factors in explaining labour migration (Stark 1991). Accordingly, economic movements are interpreted as a portfolio strategy to diversify household incomes in an environment where capital, insurance and labour markets are not functioning properly (Taylor and Martin 2001). Family members move abroad, to alleviate deprivation, to protect the family against poverty or to finance education, health care and entrepreneurial activities. In this context, the argument has been made that costs and risks of moving may not allow the most deprived households to participate in migrations (IOM 2005: 253). While the theoretical discussion on the nexus between poverty and migration is still under way, empirical observations find poverty among the root causes for movements, although the extremely poor are least likely to move from deprived regions (IOM 2005: 254).

Within the framework of the new economics of labor migration-to which this research highly relates-, migrants primarily target a specific income and return afterwards. In contrast to neoclassical theory, the new economics of labour migration has started to implicitly consider shortterm or repeated migration, although attempts to clearly distinguish both types of international movements are quite recent and plagued by conceptual difficulties as international movements

\footnotetext{
${ }^{7}$ For a comprehensive survey on migration theories see Bauer and Zimmermann (1998) and Massey et al. (1998).
} 
become increasingly diverse with respect to motivation, destination and duration patterns (Khoo, Hugo and McDonald, 2008).

In analysing the determinants of temporary labour movements, the new economics of labour migration explains migration decisions by human capital and household related variables, such as age, gender, education, work experience, household size and family structure rather than expected earnings (Mora and Taylor 2005). This allows formulating a number of testable hypotheses. Although younger persons would in general be more likely to migrate, as they have less invested in home country specific human capital compared to older age cohorts thus being less risk averse and more inclined to leave, the temporary character of movements would also allow older persons to move abroad. ${ }^{8}$ Compared to men, women are expected to have lower migration intentions, as they are typically more attached to their children and dependent relatives at home, particularly in more traditional societies (Boyd and Grieco 2004). Furthermore, education, work experience, language and other labour related skills as well as the transferability of these forms of human capital to the receiving economy are expected to be essential factors in migration decisions (Hatton and Williamson 2005). It is often assumed that higher skilled individuals have a greater motivation to go abroad, as they may face better employment opportunities and generally tend to have lower migration costs due to more effective and efficient search strategies for transportation, housing and foreign employment. In this context it is crucial whether education and skills acquired at home pay off in labour markets abroad. If sending and receiving countries differ with respect to the level of economic development, the educational system or social institutions, human capital transferability may be severely hampered. Moreover it has to be considered that under certain conditions only low-skilled segments of labour markets in receiving economies are open to immigrants, making migration less attractive for the highly-skilled as they cannot transfer their human capital (Stark and Taylor 1991). With respect to household characteristics, bigger families and households with small children might participate less in labour migration as caring for small children usually constrains parents in moving abroad. On the other hand, the responsibility for a big household with many dependents might likewise encourage labour movements in order to reduce economic pressure at home, especially if labour migration is expected to be temporary.

As all states under consideration here experienced economic and social transitions after the breakup of the Soviet Union, resulting in growing poverty, job losses, increasing social inequality, a

\footnotetext{
${ }^{8}$ In the case of permanent migration, younger individuals face higher discounted accumulated lifetime earnings and thus are more likely to migrate abroad.
} 
breakdown of social security systems and market failures, temporary labour migration in the region is considered a strategy of families and individuals to cope with the obstacles of transition societies.

\section{Data and variables}

In our empirical analysis we use survey data from Armenia, Belarus, Georgia, Moldova and Ukraine which has been collected in a multi-stage sampling framework by the EU INTAS project in the first months of 2006. ${ }^{9}$ Based on pre-existing research, two regions with substantial rates of out-migration were selected in each country (except for Moldova where households were chosen throughout the country) to question approximately 400 household, summing up to 2,003 households and 8,166 individuals in the survey. ${ }^{10}$ Households were sampled using multi-stage random selection in combination with a random routing method. The samples can be considered representative for sub-regions or migration-intensive regions throughout the Eastern European borderlands. To achieve a comparable data base, the questionnaire was identical across countries. ${ }^{11}$

In the survey, household heads were asked about socio-demographic and human capital characteristics of all family members as well as about the temporary migration experience of household members aged 16 and over. Additionally, basic information on household and settlement characteristics was collected. Temporary migrants in our sample are persons who have been abroad for work reasons at least once for a minimum of four weeks since 2004 but have returned to their country of origin after the last trip. ${ }^{12}$ Therefore it has to be kept in mind that our definition of migration is restricted to temporary labour migration and that our results cannot be generalized to other types of movements. ${ }^{13}$ We consider temporary return migrants in our survey to be representative for temporary movements in the region. In other words, we are convinced from qualitative interviews that migrants had ex-ante planned to migrate only temporarily. Although we acknowledge that some migrants might have intended to stay longer, there is no indication that our sample consists of "failed permanent migrants". This is supported by the fact that $96 \%$ of

\footnotetext{
${ }^{9}$ For a detailed project description see Wallace and Vincent (2007).

${ }^{10}$ In Ukraine, one region in the more russified Eastern part and one in the Western part were chosen.

${ }^{11}$ Starting from an English version the questionnaire was tanslated into the respective national languages.

12 The definition of temporary migrants in our survey (stay abroad for at least one month, with the length of stay not determined) differs slightly from the UN definition of short-term labour migration. According to the United Nations Department of Economic and Social Affairs, a short-term migrant is defined as a person who moves beyond the borders of his or her country of usual residence for a period of at least 3 months but less than a year (12 months) except in cases where the move is for purposes of recreation, holiday, visits to friends and relatives, business trips, medical treatment or religious pilgrimage (UN 1998: 18).

${ }^{13}$ It has to be remarked that only household heads responded to the question on future migration.
} 
temporary migrants in our survey planned to take part in temporary labour movements again (see Table 7). To the contrast, only $43 \%$ of respondents who had no temporary labour migration experience were willing to go abroad for temporary work in the near future.

The survey provides us with detailed demographic, human capital, family related and settlement information on 6,082 individuals older than 17 years living in 2,003 households in Armenia, Belarus, Georgia, Moldova and Ukraine (see Table 3). Approximately 9\% of all households contained a temporary work migrant. While some individuals experienced multiple migration spells (1.45 on average among all migrants), some households hosted more than one temporary migrant. In comparing migrants and non-migrants we find females, younger people (17-25 years old) and members of the age cohort between 56 and 65 years less engaged in moving abroad as compared to males and persons between 26 and 55 years (see Table 4). Not unusual for post Soviet societies, the level of human capital of surveyed persons is generally rather high, although educational attainment differs between migrants and non migrants. People holding university degrees are less likely to participate in migration, while those with secondary and lower education had more often left the country for temporary work.

In an effort to grasp general human capital and personal orientation towards Western societies we introduce two dummy variables: one mapping English language skills and another identifying people with no foreign language skills. In this study, English language competence is interpreted as having an orientation towards the European Union or Western societies, while no foreign language skills are considered to relate to lower human capital endowment. ${ }^{14}$ According to our survey, migrants have lower rates of English language knowledge than non migrants but also are less likely to lack any foreign language competence. ${ }^{15}$ We infer from these language patterns that migrants are well-endowed with human capital while English language knowledge appears to be an asset of the younger population. It is an outstanding feature of temporary migration from Eastern Europe that younger cohorts are under represented among migrants.

Furthermore we are interested in the ethnic background of respondents to be able to control for ethnic motivations in temporary movements. In the survey we found persons, belonging to the titular nationality-i.e. being a member of the ethnic group that comprises the eponymous majority of the nation state-more engaged in temporary migration than ethnic minorities. This indicates that work related migration is on average hardly supported by ethnic motivations.

\footnotetext{
${ }^{14}$ Despite using educational attainment as a general indicator for human capital, we additionally exploit information on language knowledge as educational degrees from the Soviet Union might not adequately reflect the current potential for income generation.

${ }^{15}$ Bilingualism (e.g. Russian and Ukrainian) was not considered as foreign language.
} 
The survey identified various family characteristics, such as household size, small children (younger than five years) and elderly (older than 60 years, but not active in the labour market) living in the household. These variables are assumed to capture factors that influence temporary movements in the family context. In our sample we find smaller households more likely to send a family member abroad, while families with small children and elderly household members were less engaged in temporary migration. In terms of settlement structure the sample allows distinguishing between persons living in rural and urban areas, and among the latter people who inhabit a regional centre can be identified by a dummy variable. According to the survey data, migrants were more frequently than non-migrants found in rural parts of sending countries, while they were much less prevalent in regional centres. In all countries under consideration, Moldova features as a high emigration region, while temporary migration movements are quantitatively of little importance in Georgia.

\section{Descriptive analysis of migration patterns across countries}

In the following, we analyse characteristics of temporary migrants and their destination choice in a cross-country comparison (see Table 5). As has already been noted, Moldova defines a region of high temporary migration incidence (19.8\%), followed by Armenia (10\%), Belarus (6.5\%), Ukraine (6.5\%) and-lagging far behind-Georgia (3\%). In the case of Moldova, the intense participation of this country in international (irregular) temporary labour migration has widely been documented (CBS AXA 2005, Cuc et al. 2005, Görlich and Trebesch 2008). The considerable, however smaller, involvement of Armenian and Ukrainian families in labour movements was recently also acknowledged (Yeganyan 2006, Danzer and Handrich 2007, Dietz 2007). To the contrast, the comparatively high temporary migration flows in Belarus come as a surprise. Unobserved by migration research, temporary migration has developed in Belarus, challenging its seemingly closed character.

Whereas temporary migration from Armenia is predominantly male, the female migration share is considerable in Belarus, Moldova, Ukraine and Georgia. A study done by Minasyan and Hancilova (2005) which found a similar high proportion of men in Armenian labour migration suggests, that traditional cultural norms and social patterns are foremost responsible for this gender bias. The high demand for male migrants in construction and agriculture in Russia is an additional argument to explain the high share of Armenian men in recent temporary movements. ${ }^{16}$ As similar traditional gender patterns could be expected for Georgia, the comparatively high female share in latest

\footnotetext{
${ }^{16}$ It should be noted that migrants to Russia traditionally work in ethnically clustered occupations.
} 
temporary migration is puzzling. Most likely this is a result of recent movements towards European Union destinations (Badurashvili 2004). The demand for household services and care jobs in Western countries seems to increasingly channel women from Georgia into temporary labour migration.

Younger age cohorts (17-35 years of age) dominated temporary movements from Moldova, Belarus and Georgia, whereas the age group of persons between 36 and 65 prevailed in Armenia and Ukraine. Educational attainment of migrants was highest in Georgia and lowest in Armenia, mirroring the skill requirements of destination regions. While temporary labour migrants from CIS countries generally work in low skilled occupations abroad, travelling to and working in Western countries certainly demand higher skills and ambitions. Self-reported English language competence was especially high in Belarus and Georgia, pointing to a stronger Western orientation of temporary migrants there.

In looking at household characteristics, migrant families were rather big in Armenia (5.2 persons), while being comparatively small in Ukraine (3.6 persons) and Belarus (3.5 persons). Between 10\% and $15 \%$ of migrant households had to care for pre-school aged children, with Armenian and Moldovan families being found at the upper bound. The share of families living with elderly persons fluctuated between $40 \%$ in the case of Armenia and $9.3 \%$ in the case of Belarus and Moldova. In all countries but Moldova, migration was less prevalent in rural areas. A high participation of Moldovans from the country side was also found by Moshneaga (2006), who argued that the less dynamic, predominantly rural part of the Moldovan labour force was engaged in recent work migration to Russia. Throughout the observation region, migration was not dominated by ethnic minorities. Repeated migration existed in all countries under consideration, with Armenia and Moldova having the highest share of circular migrants. Furthermore, the involvement of more than one household member in recent labour movements was common across the region, particularly in Georgia, Moldova and Ukraine.

Russia and other CIS states attracted the largest share of migrants from all countries under observation, except for Georgia (see Table 6 and Figure 2). According to our survey, nearly all temporary migrants from Armenia either moved to Russia (80.5\%) or to other CIS countries (15.2\%). This is very close to the results of a recent household survey conducted in Armenia which found $90 \%$ of (short term) labour migrants having left for Russia and CIS countries in the period between 2002 and 2005 (Minasyan and Hancilova 2005). With respect to migration destinations, Georgia is an exception in sending only $11 \%$ of temporary labour migrants to Russia. This reflects the severe political conflicts between Georgia and Russia which also found an expression in hostile 
attitudes towards Georgian labour migrants in the Russian Federation. In all countries under observation - with the exception of Armenia-migration was divided between Eastern and Western destinations. Belarus, Moldova, Georgia and Ukraine sent between 23\% and 40\% of their temporary migrants to European Union destinations. In Ukraine the choice of destinations depended heavily on the regional background. Migrants from the Western part of Ukraine predominantly addressed European Union countries, those from Eastern regions mostly went to Russia.

Concerning the economic welfare of surveyed households, respondents were asked to evaluate their situation according to four categories, namely food poor (families could not afford basic food and consumption goods), constrained (families had enough money only for food and basic consumption goods), satisfactory (families could afford a satisfactory living standard) and good (families had no financial problems). Of those four categories we define two groups of deprived households, namely food poor households and economically constrained households, which comprise the lowest two welfare categories. According to our survey results, migrants' households were slightly more often food poor as compared to non-migrants' households, while they were less often financially constrained (see Table 8). A country comparison revealed that migrant sending households in Armenia and Georgia were more often food poor and economically constrained than households with no migrants, while in Belarus, Moldova and Ukraine non-migrant households were generally worse off. This finding suggests that the countries are at different stages in the migration cycle.

\section{Estimation of migration determinants}

Subsequently we analyse the effects of socio-demographic, human capital, family and settlement variables on the propensity of temporary labour movements in a multivariate setting. We use a simple probit model of the following reduced form to estimate the migration determinants of individual $i$ :

$\operatorname{Pr}\left(p_{i}=1\right)=X_{i} \beta+C_{i} \gamma+\varepsilon_{i}$

The outcome variable is assumed to be normally distributed and the error term is orthogonal to the explanatory variables $X$ including human capital and household characteristics as well as country and settlement controls $C$. The variables used in our multivariate estimation analysis have been presented and described in previous parts of this study (see Tables 3, 4 and 5).

The binary dependent variable indicates whether a person has been temporary abroad for at least one month since 2004. Independent variables comprise demographic information such as gender 
and age. Education is included as a proxy for general human capital. We create three educational categories and include university degree and secondary education into the regressions. The category lower education is being omitted from the regressions as base category. An orientation towards Western societies is introduced in the form of English language skills, while no foreign language competence describes comparatively low human capital endowment. To account for household specific conditions which might prevent or hamper migration we include the household size and dummy variables for the presence of small children and elder family members. The other variables used in our estimations are controls for settlement type, ethnic affiliation and country fixed effects. Furthermore we want to explore if determinants of migration differ between men and women. The underlying assumption in the pooled full sample regression implied gender to be a shift parameter, while the split into gender sub-samples allows for qualitative differences in determinants of migration decisions. The presence of children and dependents, for instance, is expected to impact differently on the migration decisions of males and females. Besides estimating general determinants of temporary labour migration in the regression pooled over countries, we want to account for differences in migration determinants between countries under consideration. Special attention is paid to the role of unemployment as a determinant for migration. We use both, individual and household level regressions to investigate whether unemployment promotes or hinders migration.

As the welfare consequences associated with migration are of highest policy relevance, we also investigate whether households with or without past migration experience are more or less likely to be economically deprived. Again, we use a probit model to estimate the determinants of poverty of household $j$ :

$$
\operatorname{Pr}\left(p_{j}=1\right)=\text { Migration }_{j} \delta_{1}+\text { Migration }^{*} \text { Femhead }_{j} \delta_{2}+X_{j} \beta+C_{j} \gamma+\varepsilon_{j}
$$

We are especially interested in the coefficients $\delta_{1}$ and $\delta_{2}$ which report the association between past temporary labour migration (in the latter case interacted with a dummy indicating whether a household is female-headed) and current poverty status. As the decision to send a migrant abroad might be endogenous to unobserved previous levels of welfare, we test the direction of the resulting bias in the naive probit estimates by exploiting the retrospective nature of the INTAS data. If better-off households were generally more likely to send migrants, the poverty reducing effect of migration might simply reflect downward biased estimates. More specifically, we instrument the decision to send a migrant in 2005 with the probability of migration experience in 2004 in a highly significant linear first stage regression (F-value 32.5). From this we estimate a Two-stage-leastsquare estimator which should correct the downward bias of probit. Furthermore, we use the 
regional migration density of the year 2004 to control for general differences in welfare levels associated with migration.

\section{Multivariate regression results}

In the following section, we provide results for the multivariate regressions of migration determinants. Table 9 presents marginal effects of three regressions, estimating the determinants of migration for the full sample and for males and females separately. All regressions have a reasonable fit. The baseline regression shows that being a woman significantly discourages migration. The propensity to move increases with age, however, at a declining rate. The latter result indicates that people in the beginning and in the end of their working life are less engaged in moving abroad. Although the general result is broadly in line with human capital considerations and empirical findings in other parts of the world (Stark and Taylor 1991, Mora and Taylor 2005), the back loaded nature of the age-profile of migrants is surprising, especially in Armenia, Ukraine and Moldova (Figure 3). According to our estimations a university degree significantly lowers the propensity to migrate, while secondary education has no significant effect. This contrasts a number of studies which pointed to a positive correlation between education and migration (Adams 2003). However, in the context of temporary migration in former Soviet Union countries, we expect a mechanism at work similar to the case of migrations from Mexico to the USA (Mora and Taylor 2005: 47). Because a high percentage of migrants are irregular and predominantly employed in low-skilled occupations, returns to schooling obtained in the home country are negligible. This should be particularly true for Western destinations where educational attainments obtained in CIS states do in general not pay off. For the full sample, English language skills have no significant effect on temporary migrations while having no foreign language skills strongly discourages movements. In line with these results we conclude that migrants might not be particularly drawn to Western countries but nevertheless belong to the part of the population with better human capital endowment. As household size has a significantly negative effect on moving abroad, higher family obligations might prevent migration. However, small kids in the household have no influence on migration probabilities. This fact may be explained by the temporary character of movements in our study which allows keeping up family bonds while earning money abroad. Improved forms of long distance travel and communication facilities may additionally ease migration in the presence of small children at home. Elderly household members were found to significantly strengthen the likelihood to move. They seem to play a supportive role in caring for children and in performing household duties while younger (and often female) household members are away for work. 
When restricting the sample to male vs. female respondents, it becomes clear, that determinants of migration differ across gender. Age and age squared have a stronger and more significant effect on men, indicating that very young and older men are less likely to migrate as compared to their female counterparts. We explain this pattern by the demand structure for labour migrants abroad: While men mostly work in construction or agriculture, i.e. heavy labour, the highest demand for women is in home caring and nursing which can be performed almost without age restrictions (Ehrenreich and Hochschild 2002). Being a university graduate discourages men from migration, while education does not play a significant role for female migrants. This is explained by better chances of highly educated men to find employment according to their skills at home. It is interesting to note that women with English language skills are significantly less likely to engage in migration, while this factor is irrelevant for men. Nevertheless, having no foreign language skills discourages men and women strongly from moving abroad. As expected, the presence of small children has a discouraging effect for women, but not for men. Likewise, elderly family members in the household only encourage women to leave, thus emphasizing the supportive role of older household members with respect to family obligations.

In a next step we explore if determinants of migration differ between sending regions, using separate regressions for countries under consideration (Table 10). As expected, the regressions exhibit lower fits due to smaller sample sizes. While females were strongly discouraged from migration in Armenia, Belarus and Moldova, no significant gender effect on migration could be found in Georgia and Ukraine. As has already been discussed earlier, the demand structure in destination regions might be responsible for that pattern. Although the inverse U-shaped age-migration nexus could be observed in all countries under observation, it is not significant in the case of Georgia and Belarus. In both countries, younger age cohorts were likewise drawn into migration movements. With respect to educational attainment, a university education significantly promotes temporary movements in Georgia while it discourages them in Moldova. This pattern is likewise reflected in looking at English language skills which had a significantly positive sign in the case of Georgia and a negative in Moldova. Furthermore it has to be remarked that lacking foreign language skills discouraged people from migration across all countries under consideration, although this variable was only significant in the case of Moldova and Ukraine.

In Belarus and Ukraine household size significantly lowered migration probabilities pointing to the discouraging effect on migrations of big households in these countries. Small children prevented temporary movements only in Armenia where traditional family structures are particularly strong. The supportive effect of elderly family members was exclusively significant in the case of Moldova, confirming the immense relevance of aiding family members in this country with extremely high 
migration intensity. While in Ukraine, people living in rural areas were less likely to be drawn into temporary movements, the migration participation of rural inhabitants was significantly higher in Belarus. We expect economic performance in the respective regions to explain this pattern.

Individual unemployment is a strong determinant for migration in Belarus $(+14.5 \%)$ and Ukraine (+6.8\%), while the results for Armenia and Georgia suggest that unemployment may render migration impossible in generally poorer countries (Table 11). On the household level, we see the robust finding across countries, that unemployment (of at least one household member) increases the propensity to move strongly. Only in Georgia the effect is negative. Overall, these results suggest that albeit households respond to unemployment with sending a migrant abroad, they might send the most promising household member rather than the unemployed individual.

The results of our estimations are robust with respect to variable selection and model extensions. ${ }^{17}$ Initially we proved this by repeating the baseline and the male versus female regressions using regionally clustered standard errors finding very similar results. In a further test we included the variable regional centre, and titular nationality identifying the ethnic background of individuals. Living in a regional centre negatively influenced migration intentions only in the case of men, probably referring to better labour market chances for males in a more urban setting. Including titular nationality in the baseline model showed that nationals were more likely to temporarily move abroad, although this result was only significant in the baseline model and for the male sample. Otherwise, the coefficients of original regressions were not affected. Furthermore, we tested whether relaxing the sample age restriction, i.e. including adults above 65 years, would change the country related estimations which was not the case. Also, the educational variable was replaced by years of schooling which had only a marginal effect in the case of Georgia, where years of schooling turned insignificant, although university and secondary education had significantly encouraged migration in the original estimation.

Our poverty estimation suggests that migrants' households are $4.9 \%$ less likely to be economically constrained compared to non-migrants' households but neither more nor less likely to be food poor, i.e. unable to afford the required minimum food consumption (Table 12). Other poverty correlates show the expected signs with female-headed households and larger households being more likely to be economically constrained as well as households from rural and regional centre settlement being less likely to be economically constrained. ${ }^{18}$ When introducing the interaction between migration incidence and female-headedness of the household, the negative association between deprivation

\footnotetext{
${ }^{17}$ Results are not reported but available from the authors upon request.

${ }^{18}$ The lower deprivation rates among rural households can be explained by the widespread phenomenon of subsidiary farming activities.
} 
status and past migration becomes even larger (-6.7\%). Interestingly, after inclusion of the interaction term, migrant households are also $2.7 \%$ less likely to be food poor, while female-headed migrant households are $4.4 \%$ more likely to be food poor. However, one general caveat in the analysis of the poverty-migration nexus is the question of reverse causation. Potentially, less deprived households were simply better able to finance the migration of a household member. To test the direction of the potential bias in our estimates, we first compare households with different migration experiences. As becomes clear form Table 13, households which had a migrant neither in 2004 nor in 2005 were quite similar to households which had a migrant in both years with respect to poverty. Unlike those, households which had a migrant only in one of the two years were significantly less likely to be economically constrained at the time of the survey. Furthermore the analysis shows that past migration experience of a household was a good predictor for migration in early 2006. Although being no perfect test of causation, this result suggests that economically constrained households could afford to send migrants. In Table 14 we extend this analysis and focus on the conditional impact of migration in 2004 on current poverty level when controlling for general welfare shifts between regions of different migration intensity (in early 2004, before the EU enlargement). We not only find that migration intense regions have generally lower poverty rates (by 1.3 percentage points) but also that household level migration is still negatively associated with poverty. As column 2 shows, the long term poverty reducing effect was only significant for households headed by a woman. In the next step we instrument household migration in the year 2005 with migration propensity in 2004. If the naive probit estimates were biased, we would expect the coefficient to move closer to zero. However, we observe the opposite. Although this instrumentation does not suggest clear causality, it points to the fact that the negative coefficient on migration is not merely driven by welfare gains previous to the recent migration spells.

\section{Summary and Policy Implications}

This paper explored temporary migration movements and their determinants in five former Soviet Union countries-Armenia, Belarus, Georgia, Moldova and Ukraine_-after the enlargement of the European Union in 2004. Across sending countries, temporary migration incidence differed considerably. While Moldova faced a high temporary labour emigration since 2004, Armenia, Belarus and Ukraine were confronted with a more moderate outflow. To the contrast, temporary labour movements from Georgia were quite low. With respect to destination regions, Russia and other CIS countries attracted the majority of temporary migrants in the case of Armenia, Belarus, 
Moldova and Ukraine, while Georgian labour migrants headed predominantly for European and overseas destinations.

Among the most important determinants to migrate we found individual demographic characteristics and household composition. These determinants did not generally differ from what is observed in other parts of the world. However, we identified some peculiarities such as a relatively back loaded inverse U-shaped age-migration nexus, a negative impact of university education and a rather low influence of family obligations on migration decisions. Individual unemployment is a strong determinant for migration only in Belarus and Ukraine while unemployment on the household level generally increases the propensity to send a migrant. Thus, albeit households respond to unemployment with sending a migrant abroad, they might send the most promising household member rather than the unemployed individual.

The analysis showed that past migration is associated with significantly lower current household deprivation as long as the household was not female-headed. Simple comparisons of deprivation across households with repeated migration spells suggest that migration indeed reduces poverty. This finding is supported by a two-stage IV estimation which finds no systematic downward bias in the migration impact on poverty.

Several policy implications can be drawn from our analysis, both for the countries of origin and the countries of destination. Fears of brain drain have not been substantiated in our analysis on temporary labour migration, although the results may differ in the case of permanent movements. A major drawback for migrant sending countries lies in the potential for social problems in families. As noted above, the presence of small children does not prevent from migration. Although elderly household members support temporary migrants in caring for kids and other duties at home, social policy has to be aware of the detrimental social effects, potentially resulting from temporary labour movements. In Moldova and Ukraine increasing numbers of social orphans have been observed in recent years, as their parents went abroad for work. ${ }^{19}$ However, migration is associated with lower poverty incidence among households. So far it remains unclear, whether migration causally reduces poverty or whether better-off households are simply more likely to afford migration. Future research should focus on this issue as the direction of causality will determine whether migration causes increasing or decreasing inequality within societies.

As concerns the countries of destination we restrict ourselves to two major implications for the European Union which are of high importance in the political debate. Despite focussing on short term migration only, we want to stress that the majority of temporary labour migrants from the

\footnotetext{
${ }^{19}$ We thank Natalia Astapova from the UNICEF office Kiev for this information.
} 
Eastern borderlands was directed towards Russia and other CIS countries. However, there is also a remarkable part of migrants addressing European Union countries. European Union politicians should be aware that the demand for immigrants in low skilled professions is increasingly satisfied by Eastern Europeans, temporarily moving to European Union countries. As many of them currently work on an irregular basis, effective migration regulation schemes should be considered. Second, the educational background of migrants from Eastern European countries to the EU is rather low. Albeit the EU increasingly intends to attract highly qualified workers, the supply of a highly skilled work force from Eastern Europe in the framework of temporary migration seems unrealistic in the near future. 


\section{References}

Adams, Jr., Richard H., 2003. International Migration, Remittances and the Brain Drain: A Study of 24 Labor-Exporting Countries. World Bank Policy Research Working Paper, No. 3069. World Bank, Washington DC.

Badurashvili, Irina, 2004. Determinants and Consequences of Irregular Migration in a Society under Transition: The Case of Georgia. Paper presented at the Population Association of America Annual Meeting, Philadelphia.

Bauer, Thomas K., Zimmermann, Klaus F., 1998. Causes of International Migration: A Survey, in: Gorter, Cees, Nijkamp, Peter, Poot, Jacques (eds.), Crossing Borders: Regional and Urban Perspectives on International Migration. Ashgate: Aldershot, pp. 95-127.

Boyd, Monica, Grieco, Elizabeth M., 2004. Women and Migration: Incorporating Gender into International Migration Theory. Migration Policy Institute, Washington DC.

Brubaker, Rogers, 1998. Migration of Ethnic Unmixing in the 'New Europe'. International Migration Review 32, 1047-1065.

Brücker, Herbert, 2007. Labor Mobility after the European Union's Eastern Enlargement: Who Wins, Who Loses? GMF Paper Series. Washington DC.

Cassarino. Jean-Pierre, 2004. Theorizing Return Migration: The Conceptual Approach to Return Migrants Revised. International Journal on Multicultural Societies 6, 253-279.

CBS AXA Consultancy, 2005. Migration and Remittances in Moldova. Report prepared for the IOM, EC and IMF. CBS AXA, Chisinau.

Constant, Amelie, Massey, Douglas S., 2002. Return Migration by German Guestworkers: Neoclassical vs. New Economic Theories. International Migration 40, 5-38.

Cuc, Milan, Lundbäck, Erik, Ruggiero, Edgardo, 2005. Migration and Remittances in Moldova. IMF, Washington DC. 
Danzer, Alexander M., Handrich, Lars, 2007. Should I Stay or Should I Go? Ukrainian Migration in Economic Perspective. Advisory Paper W11. Institute for Economic Research and Policy Consulting, Kyiv.

Dietz, Barbara, 2007. Migration policy challenges at the new Eastern borders of the enlarged European Union: The Ukrainian Case. Arbeiten aus dem Osteuropa-Institut Nr. 267, Munich. Duleep, Harriet O., 1994. Social security and the emigration of immigrants. Social Security Bulletin 57, 37-52.

Ehrenreich, Barbara, Hochschild, Arlie R. (eds.), 2002. Global Women: Nannies, Maids, and Sex Workers in the New Economy. Holt, New York.

European Bank of Reconstruction and Development (EBRD), 2007. Transition report 2007. People in Transition.

Görlich, Dennis, Trebesch, Christoph, 2008. Seasonal Migration and Networks: Evidence on Moldova’s Labour Exodus. Review of World Economics 144, 107-133.

Harris, John R., Todaro, Michael P., 1970. Migration, Unemployment, and Development: A TwoSector Analysis. American Economic Review 60, 126-142.

Hatton, Timothy J., Williamson, Jeffrey G., 2005. What Fundamentals Drive World Migration?, in: Borjas, George J., Crisp, Jeff (eds.), Poverty International Migration and Asylum, PalgraveMacmillan, pp. 15-38.

Hönekopp, Elmar, Mattila, Heikki, 2008. Permanent or Circular Migration? Policy Choices to Address Demographic Decline and Labour Shortages in Europe. IOM, Geneva.

International Organization for Migration (IOM), 2005. World Migration 2005: Costs and Benefits of International Migration. IOM, Geneva.

International Organization for Migration (IOM), 2008. World Migration 2008: Managing Labour Mobility in the Evolving Global Economy. IOM, Geneva. 
Ivakhnyuk, Irina, 2006. Migration in the CIS Region: Common Problems and Mutual Benefits. International Symposium on International Migration and Development, Population Division. UN DESA, Turin.

Khoo, Siew-Ean, Hugo, Graeme, McDonald, Peter, 2008. Which Skilled Temporary Migrants Become Permanent Residents and Why? International Migration Review 42, 193-226.

Malynovska, Olena, 2006. Caught between East and West. Ukraine struggles with its Migration Policy. Migration Information Source.

Mansoor, Ali, Quillin, Bryce, 2006. Migration and Remittances. Eastern Europe and the Former Soviet Union. World Bank, Washington DC.

Massey, Douglas S., Arango, Joaquin, Hugo, Graeme, Kouaouci, Ali, Pellegrino Adela, Taylor J. Edward, 1998. Worlds in Motion. Understanding International Migration at the End of the Millennium. Clarendon Press, Oxford.

Minasyan, Anna, Hancilova, Blanka, 2005. Labor Migration from Armenia in 2002-2005. A Sociological Survey of Households. OSCE and Advanced Social Technologies NGO, Yerevan.

Mora, Jorge, Taylor, J. Edward, 2005. Determinants of Migration, Destination and Sector Choice: Disentangling Individual, Household and Community Effects, in: Özden, Caglar, Schiff, Maurice (eds.), International Migration, Remittances, and the Brain Drain. World Bank, Washington DC, pp. 21-51.

Moshneaga, Valeriu, 2006. Implications of International Labour Migration for the Population of the Republic of Moldova, in: Rios, Rodriguez R. (ed.), Migration Perspectives. Eastern Europe and Central Asia. IOM, Vienna, pp. 55-69.

Organisation for Economic Co-operation and Development (OECD), 2006. International Migration Outlook. Annual Report 2006. OECD, Paris.

Sjaastad, Larry A., 1962. The Costs and Returns of Human Migration. The Journal of Political Economy 70, 80-93. 
Stark, Oded, Taylor, J. Edward, 1991. Migration Incentives, Migration Types: The Role of Relative Deprivation. The Economic Journal 101, 1163-1178.

TransMONEE, 2008. Database. UNICEF Innocenti Research Centre. Florence.

United Nations - Department of Economic and Social Affairs, Statistical Division, 1998. Recommendations on Statistics of International Migration. Revision 1. Statistical Paper Series M, No. 8, Rev. 1. United Nations, New York.

Wallace, Claire, Vincent, Kathryn, 2007. Recent Migration from the New European Borderlands. Review of Sociology 13, 1-15.

Yeganyan, Gagik, 2006. The Migration Situation in Armenia: Challenges and Solutions, in: Rios, Rodriguez R. (ed.), Migration Perspectives. Eastern Europe and Central Asia. IOM, Vienna, pp. 17-26. 


\section{Appendix}

Figure 1: Net migration, Armenia, Georgia, Belarus, Moldova, Ukraine (1991-2006, in thousand)

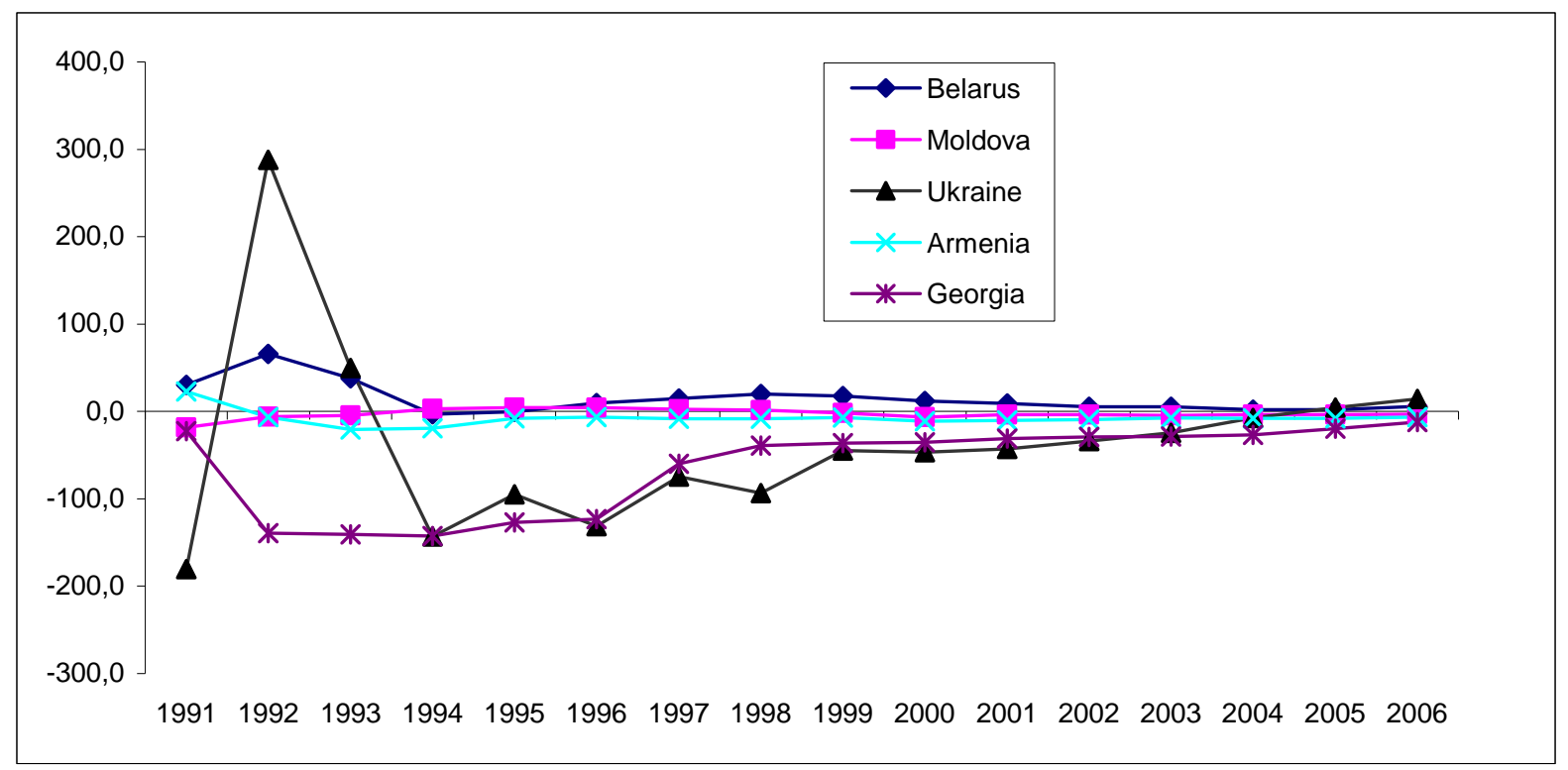

Source: Transmonee Database, 2008

Table 1: GPD per capita (PPP, 2005 constant US \$), Armenia, Belarus, Georgia, Moldova, Ukraine, Russia, various European Union countries

\begin{tabular}{lrrrrrrr}
\hline & 2000 & 2001 & 2002 & 2003 & 2004 & 2005 & 2006 \\
\hline \hline Germany & 29,582 & 29,904 & 29,840 & 29,772 & 30,153 & 30,444 & 31,323 \\
Italy & 27,591 & 28,070 & 28,079 & 27,872 & 27,931 & 27,749 & 28,155 \\
Portugal & 17,095 & 17,751 & 18,523 & 19,167 & 19,952 & 19,956 & 20,141 \\
Czech Rep. & 16,773 & 17,267 & 17,635 & 18,268 & 19,094 & 20.280 & 21,435 \\
Poland & 11,540 & 11,741 & 11,917 & 12,389 & 13,056 & 13,534 & 14.378 \\
Armenia & 2,289 & 2,523 & 2,869 & 3,285 & 3,642 & 4,161 & 4,728 \\
Belarus & 5,810 & 6,105 & 6,443 & 6,932 & 7,765 & 8,540 & 9,431 \\
Georgia & 2,341 & 2,481 & 2,648 & 2,974 & 3,180 & 3,520 & 3,886 \\
Moldova & 1,455 & 1,565 & 1,710 & 1,848 & 2,012 & 2,190 & 2,303 \\
Ukraine & 3,689 & 4,069 & 4,324 & 4,777 & 5,396 & 5,583 & 6,020 \\
Russia & 8,613 & 9,073 & 9,546 & 10,297 & 11,090 & 11,858 & 12,710 \\
\hline \hline
\end{tabular}

Source: World Bank, World Development Indicators 08 
Table 2: Human development index (HDI)*, Armenia, Belarus, Georgia, Moldova, Ukraine, Russia, various European Union countries

\begin{tabular}{lrc}
\hline & \multicolumn{2}{c}{$\begin{array}{c}\text { Human development index } \\
\text { 2005 }\end{array}$} \\
\hline \hline Spain & 13 & 0.949 \\
Italy & 20 & 0.942 \\
Germany & 27 & 0.935 \\
Portugal & 29 & 0.897 \\
Czech Rep. & 32 & 0.891 \\
Poland & 37 & 0.870 \\
Belarus & 64 & 0.804 \\
Russia & 67 & 0.802 \\
Ukraine & 76 & 0.788 \\
Armenia & 83 & 0.775 \\
Georgia & 96 & 0.754 \\
Moldova & 111 & 0.708 \\
\hline \hline
\end{tabular}

*The HDI is a summary composite index that measures a country's average achievements in health, knowledge and a decent standard of living. Health is measured by life expectancy at birth; knowledge by a combination of the adult literacy rate and the combined primary, secondary, and tertiary gross enrolment ration; and standard of living by GDP per capita (PPP US\$).

Source: United Nations, Human Development Report 2007/2008 
Table 3: INTAS data set, variable overview

\begin{tabular}{lrrrr}
\hline Variable name & Observations & Mean & Min & Max \\
\hline \hline Female & 6082 & 0.518 & 0 & 1 \\
Age 17-25 & 6082 & 0.276 & 0 & 1 \\
Age 26-35 & 6082 & 0.206 & 0 & 1 \\
Age 36-55 & 6082 & 0.446 & 0 & 1 \\
Age 56+ & 6082 & 0.067 & 0 & 1 \\
University education & 6082 & 0.292 & 0 & 1 \\
Secondary education & 6082 & 0.646 & 0 & 1 \\
Lower education & 6082 & 0.062 & 0 & 1 \\
English & 6082 & 0.194 & 0 & 1 \\
No foreign language & 6082 & 0.581 & 0 & 1 \\
Household size & 6082 & 4.283 & 1 & 10 \\
Children (0-5 yrs) & 6082 & 0.153 & 0 & 1 \\
Elderly in the household & 6082 & 0.244 & 0 & 1 \\
Rural & 6082 & 0.310 & 0 & 1 \\
Regional centre & 6082 & 0.222 & 0 & 1 \\
Titular nationality & 6082 & 0.921 & 0 & 1 \\
Unemployed & 6082 & 0.157 & 0 & 1 \\
Armenia & 6082 & 0.212 & 0 & 1 \\
Belarus & 6082 & 0.190 & 0 & 1 \\
Georgia & 6082 & 0.214 & 0 & 1 \\
Moldova & 6082 & 0.197 & 0 & 1 \\
Ukraine & 6082 & 0.187 & 0 & 1 \\
Temporary migration & 6082 & 0.091 & 0 & 1 \\
Migration 2004 & 6082 & 0.041 & 0 & 1 \\
Migration 2005 & 6082 & 0.051 & 0 & 1 \\
Number of stays abroad & 6082 & 0.145 & 0 & 4 \\
Number of migrants in household & 6082 & 0.301 & 0 & 5 \\
\hline \hline Soure: INTs; & & & &
\end{tabular}

Source: INTAS; authors' calculations. 
Table 4: Profiles of migrants and non-migrants

\begin{tabular}{lrrr}
\hline & Migrants & Non-migrants & Full sample \\
\hline \hline Female & $36.2 \%$ & $53.4 \%$ & $51.8 \%$ \\
Age 17-25 & $25.5 \%$ & $27.8 \%$ & $27.6 \%$ \\
Age 26-35 & $27.2 \%$ & $19.9 \%$ & $20.6 \%$ \\
Age 36-55 & $44.4 \%$ & $44.6 \%$ & $44.6 \%$ \\
Age 56+ & $2.9 \%$ & $7.1 \%$ & $6.7 \%$ \\
University education & $18.5 \%$ & $30.3 \%$ & $29.2 \%$ \\
Secondary education & $72.1 \%$ & $63.8 \%$ & $64.6 \%$ \\
Lower education & $9.4 \%$ & $5.9 \%$ & $6.2 \%$ \\
English & $17.3 \%$ & $19.6 \%$ & $19.4 \%$ \\
No foreign language & $54.0 \%$ & $58.5 \%$ & $58.1 \%$ \\
Household size & 4.19 & 4.29 & 4.28 \\
Children (0-5 yrs) & $14.2 \%$ & $15.4 \%$ & $15.3 \%$ \\
Elderly in the household & $19.8 \%$ & $24.9 \%$ & $24.4 \%$ \\
Rural & $40.1 \%$ & $30.1 \%$ & $31.0 \%$ \\
Regional center & $13.3 \%$ & $23.1 \%$ & $22.2 \%$ \\
Titular nationality & $94.4 \%$ & $91.8 \%$ & $92.1 \%$ \\
Observations & 556 & 5526 & 6082 \\
\hline \hline
\end{tabular}

Source: INTAS; authors' calculations.

Table 5: Migrants profiles, by country of origin

\begin{tabular}{lrrrrr}
\hline & Armenia & Belarus & Georgia & Moldova & Ukraine \\
\hline Female & $9.2 \%$ & $38.7 \%$ & $48.7 \%$ & $45.1 \%$ & $45.3 \%$ \\
Age 17-25 & $26.9 \%$ & $45.3 \%$ & $41.0 \%$ & $19.8 \%$ & $13.3 \%$ \\
Age 26-35 & $20.0 \%$ & $28.0 \%$ & $23.1 \%$ & $31.6 \%$ & $26.7 \%$ \\
Age 36-55 & $46.9 \%$ & $25.3 \%$ & $33.3 \%$ & $47.7 \%$ & $54.7 \%$ \\
Age 56+ & $6.2 \%$ & $1.3 \%$ & $2.6 \%$ & $0.8 \%$ & $5.3 \%$ \\
University education & $13.8 \%$ & $28.0 \%$ & $46.2 \%$ & $11.8 \%$ & $24.0 \%$ \\
Secondary education & $83.1 \%$ & $70.7 \%$ & $53.8 \%$ & $69.2 \%$ & $73.3 \%$ \\
Lower education & $3.1 \%$ & $1.3 \%$ & $0.0 \%$ & $19.0 \%$ & $2.7 \%$ \\
English & $3.1 \%$ & $49.3 \%$ & $53.8 \%$ & $8.0 \%$ & $20.0 \%$ \\
No foreign language & $91.4 \%$ & $38.6 \%$ & $20.5 \%$ & $51.9 \%$ & $29.3 \%$ \\
Household size & 5.18 & 3.51 & 4.21 & 4.04 & 3.65 \\
Children (0-5 yrs) & $15.4 \%$ & $10.7 \%$ & $10.3 \%$ & $15.6 \%$ & $13.3 \%$ \\
Elderly in the household & $40.0 \%$ & $9.3 \%$ & $30.8 \%$ & $9.3 \%$ & $22.7 \%$ \\
Rural & $15.6 \%$ & $29.3 \%$ & $33.3 \%$ & $62.4 \%$ & $22.6 \%$ \\
Regional center & $0.0 \%$ & $42.7 \%$ & $43.6 \%$ & $10.5 \%$ & $25.3 \%$ \\
Titular nationality & $98.4 \%$ & $88.0 \%$ & $100.0 \%$ & $94.1 \%$ & $92.0 \%$ \\
Number of stays & 1.28 & 1.04 & 1.10 & 1.26 & 1.03 \\
Number of migrants in household & 1.26 & 1.19 & 1.44 & 1.57 & 1.40 \\
Observations & 130 & 75 & 39 & 237 & 75 \\
\hline \hline
\end{tabular}

Source: INTAS; authors' calculations. 
Table 6: Migration patterns, by country of origin

\begin{tabular}{rrrrrrr}
\hline & Armenia & Belarus & Georgia & Moldova & Ukraine & Total \\
\hline \hline Migration & $\mathbf{1 0 . 0 7 \%}$ & $\mathbf{6 . 5 0 \%}$ & $\mathbf{3 . 0 0 \%}$ & $\mathbf{1 9 . 8 0 \%}$ & $\mathbf{6 . 5 8 \%}$ & $\mathbf{9 . 1 4 \%}$ \\
Destination Europe & $2.78 \%$ & $23.08 \%$ & $30.43 \%$ & $32.28 \%$ & $39.83 \%$ & $25.92 \%$ \\
Destination Russia & $80.56 \%$ & $27.35 \%$ & $10.87 \%$ & $44.91 \%$ & $21.19 \%$ & $43.10 \%$ \\
Destination CIS & $15.28 \%$ & $40.17 \%$ & $28.26 \%$ & $20.70 \%$ & $35.59 \%$ & $25.77 \%$ \\
Destination Overseas & $1.39 \%$ & $9.40 \%$ & $30.43 \%$ & $2.11 \%$ & $3.39 \%$ & $5.21 \%$ \\
& $100 \%$ & $100 \%$ & $100 \%$ & $100 \%$ & $100 \%$ & $100 \%$ \\
Migration Incidence 2004 & $\mathbf{4 . 9 6 \%}$ & $\mathbf{2 . 9 5 \%}$ & $\mathbf{0 . 6 9 \%}$ & $\mathbf{9 . 3 6 \%}$ & $\mathbf{2 . 7 2 \%}$ & $\mathbf{4 . 1 1 \%}$ \\
Migration Incidence 2005 & $\mathbf{4 . 4 2 \%}$ & $\mathbf{3 . 3 8 \%}$ & $\mathbf{1 . 7 7 \%}$ & $\mathbf{1 2 . 0 3 \%}$ & $\mathbf{4 . 2 1 \%}$ & $\mathbf{5 . 1 1 \%}$ \\
Year-to-year change & $-10.94 \%$ & $14.71 \%$ & $155.56 \%$ & $28.57 \%$ & $54.84 \%$ & $24.40 \%$ \\
Percentage women migrants & $\mathbf{9 . 2 3 \%}$ & $\mathbf{3 8 . 6 7 \%}$ & $\mathbf{4 8 . 7 2 \%}$ & $\mathbf{4 5 . 1 5 \%}$ & $\mathbf{4 5 . 3 3 \%}$ & $\mathbf{3 6 . 1 5 \%}$ \\
Observations & 1291 & 1153 & 1302 & 1197 & 1139 & 6082 \\
\hline \hline
\end{tabular}

Source: INTAS; authors’ calculations.

Figure 2: Migration destinations by country of origin

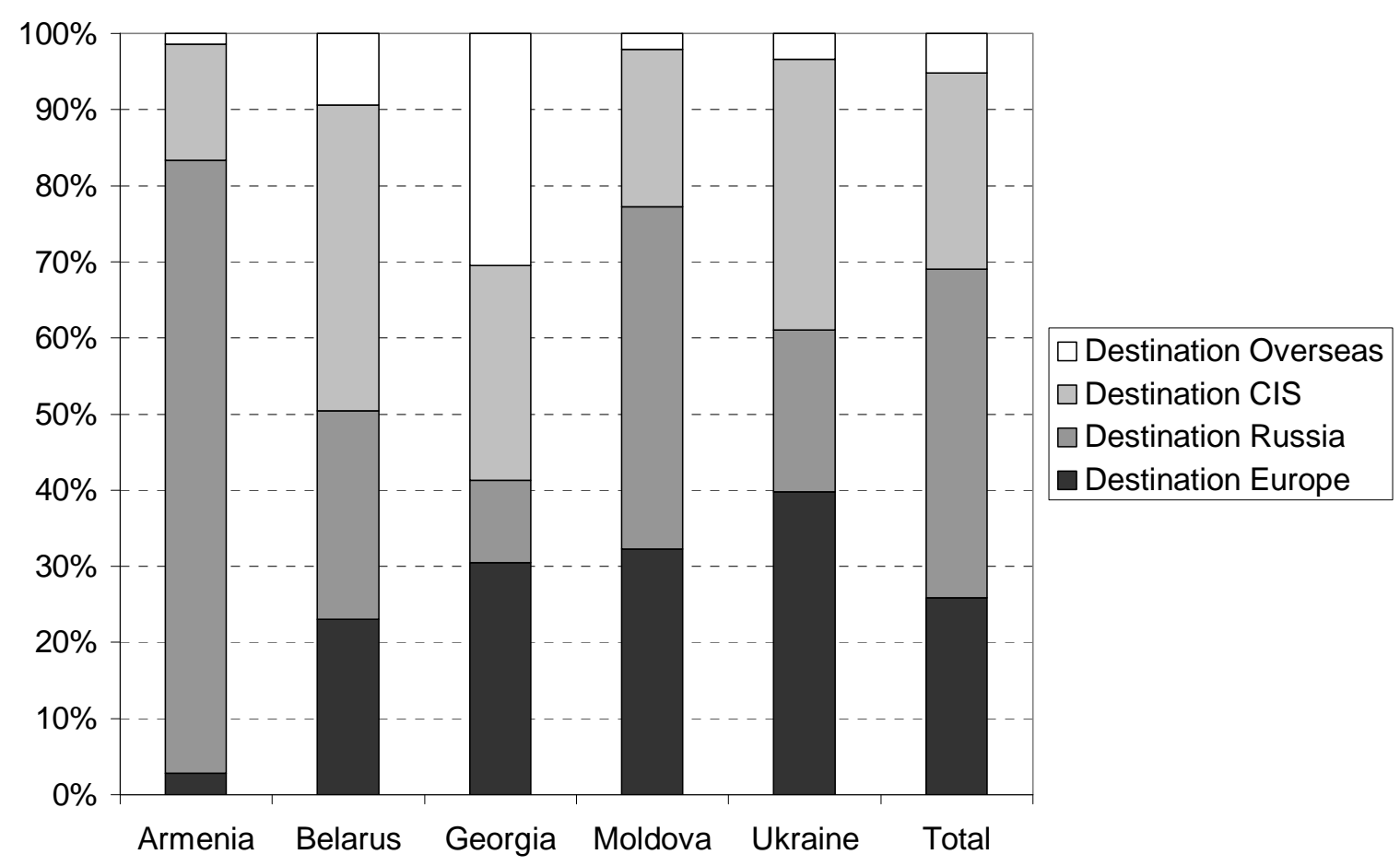

Source: INTAS; authors’ calculations. 
Table 7: Prevalence of future migration plans by migration experience

\begin{tabular}{lrr}
\hline & $\begin{array}{r}\text { With migration } \\
\text { experience }\end{array}$ & $\begin{array}{r}\text { Without migration } \\
\text { experience }\end{array}$ \\
\hline \hline Armenia & $92.3 \%$ & $34.9 \%$ \\
Belarus & $100.0 \%$ & $39.8 \%$ \\
Georgia & $85.7 \%$ & $46.7 \%$ \\
Moldova & $98.1 \%$ & $56.9 \%$ \\
Ukraine & $93.6 \%$ & $38.5 \%$ \\
& & \\
Age 17 - 25 & $93.8 \%$ & $60.4 \%$ \\
Age 26 - 35 & $97.4 \%$ & $48.9 \%$ \\
Age 36 - 55 & $97.3 \%$ & $34.1 \%$ \\
Age 56+ & $100.0 \%$ & $20.0 \%$ \\
Total & & \\
Observations & $\mathbf{9 6 . 3 \%}$ & $\mathbf{4 3 . 2 \%}$ \\
\hline \hline
\end{tabular}

Source: INTAS; authors' calculations.

Table 8: Poverty status in households with and withoutmigrants

\begin{tabular}{|c|c|c|c|c|}
\hline & & $\begin{array}{r}\text { Non- } \\
\text { migrants }\end{array}$ & Migrants & Total \\
\hline \multirow[t]{2}{*}{ Armenia } & Constrained & $81.3 \%$ & $82.6 \%$ & $81.4 \%$ \\
\hline & Food poor & $26.5 \%$ & $27.1 \%$ & $26.5 \%$ \\
\hline \multirow[t]{2}{*}{ Belarus } & Constrained & $38.9 \%$ & $27.4 \%$ & $38.3 \%$ \\
\hline & Food poor & $0.7 \%$ & $0.0 \%$ & $0.7 \%$ \\
\hline \multirow[t]{2}{*}{ Georgia } & Constrained & $75.4 \%$ & $77.4 \%$ & $75.4 \%$ \\
\hline & Food poor & $10.7 \%$ & $12.5 \%$ & $10.7 \%$ \\
\hline \multirow[t]{2}{*}{ Moldova } & Constrained & $71.8 \%$ & $66.7 \%$ & $70.8 \%$ \\
\hline & Food poor & $17.5 \%$ & $14.5 \%$ & $17.0 \%$ \\
\hline \multirow[t]{2}{*}{ Ukraine } & Constrained & $54.4 \%$ & $42.6 \%$ & $53.7 \%$ \\
\hline & Food poor & $5.7 \%$ & $5.7 \%$ & $5.7 \%$ \\
\hline \multirow[t]{2}{*}{ Total } & Constrained & $66.8 \%$ & $64.7 \%$ & $66.7 \%$ \\
\hline & Food poor & $13.4 \%$ & $15.3 \%$ & $13.5 \%$ \\
\hline
\end{tabular}

Note: „constrained“ refers to economically constrained and food poor households; „food poor“ means that households cannot meet basic nutritional requirements.

Source: INTAS; authors' calculations. 
Figure 3: Actual and predicted age-migration profiles

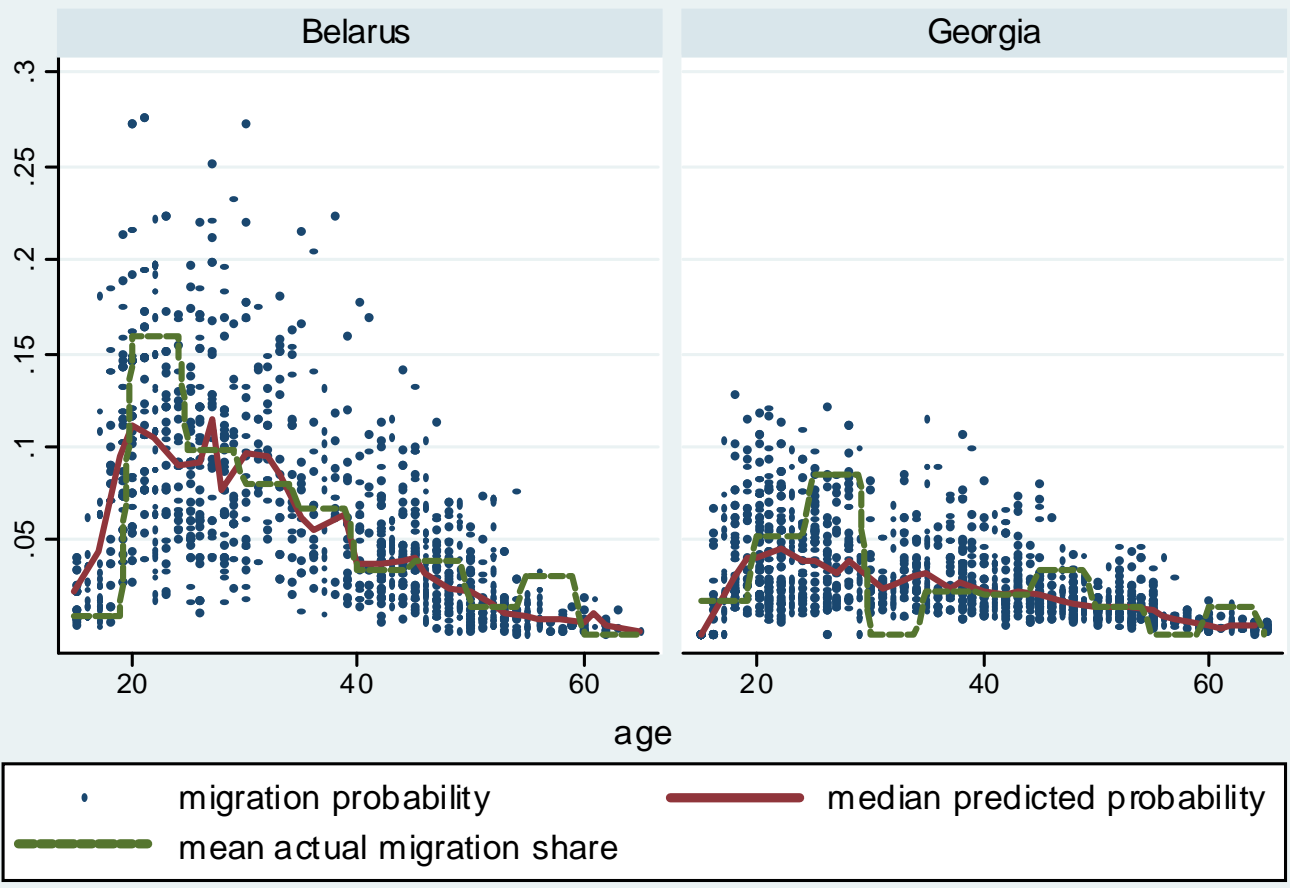

Graphs by country

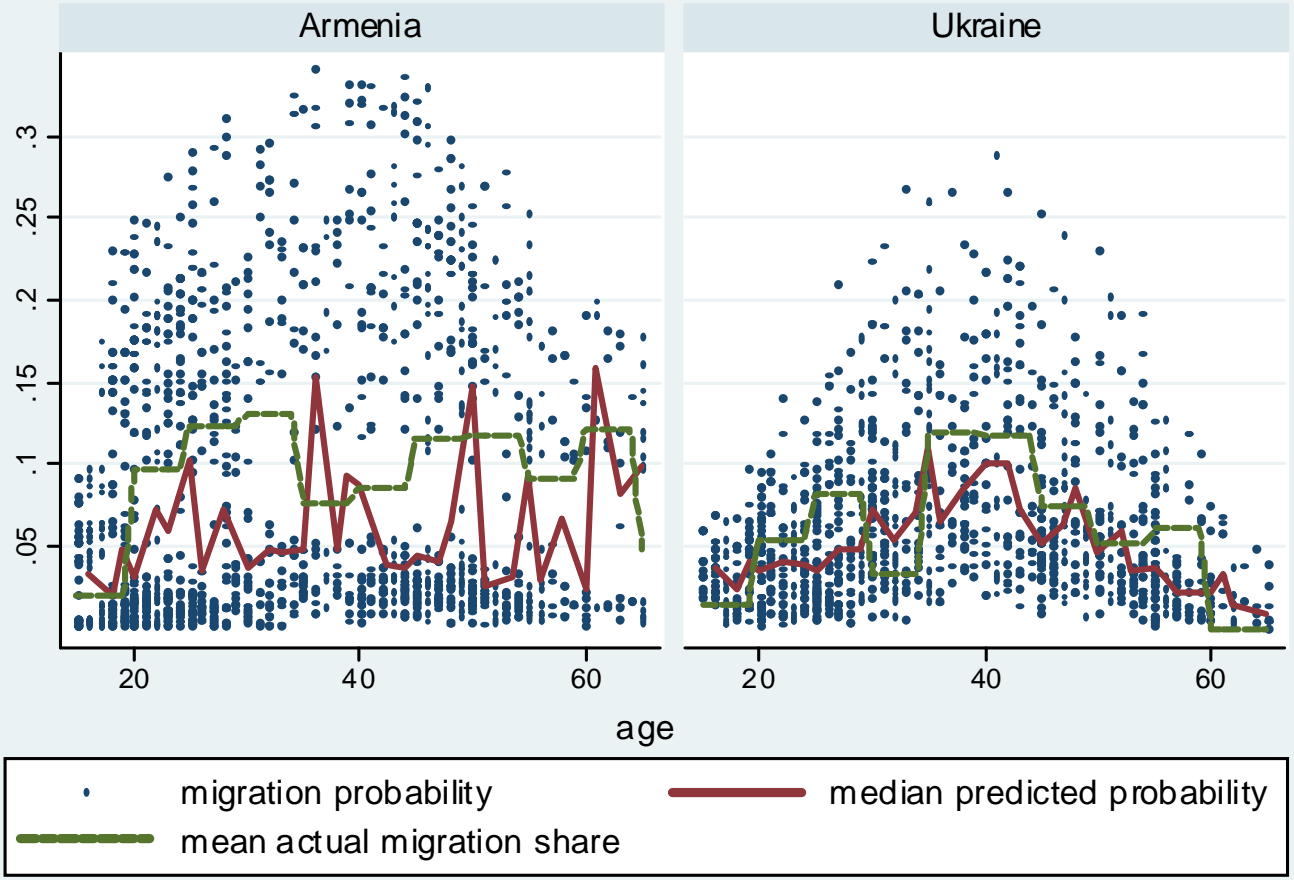

Graphs by country 


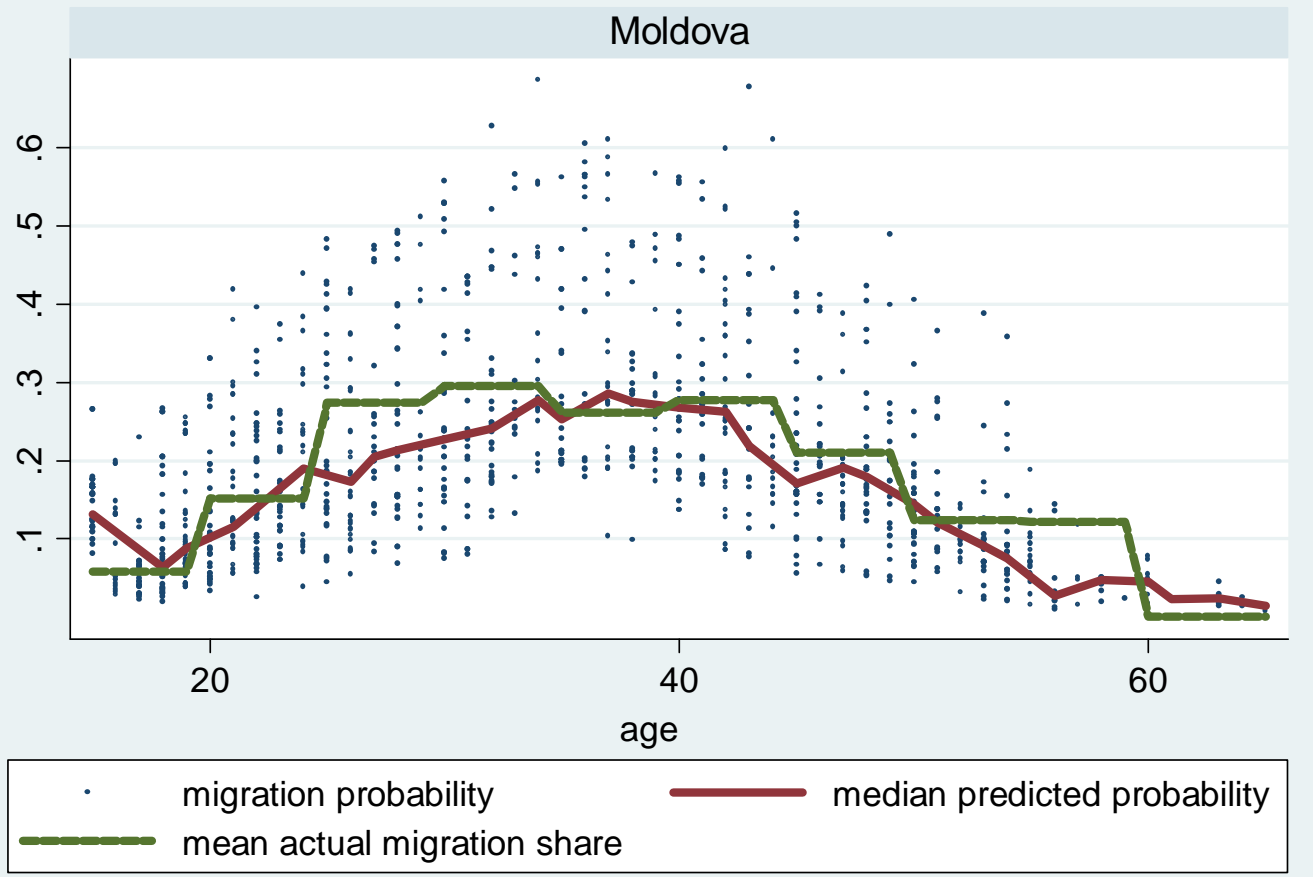

Graphs by country

Note: Mean actual migration shares are calculated for 5-year age brackets starting at age of 15 . The scale for Moldova differs from other countries' scales.

Source: INTAS; authors' calculations. 
Table 9: Probit Regressions of determinants of migration, full sample; adults 16-65

\begin{tabular}{|c|c|c|c|}
\hline & $\begin{array}{c}\text { (1) } \\
\text { Baseline model }\end{array}$ & $\begin{array}{l}(2) \\
\text { Men }\end{array}$ & $\begin{array}{c}(3) \\
\text { Women }\end{array}$ \\
\hline Female & $\begin{array}{l}-0.055 \\
(8.51)^{* * *}\end{array}$ & & \\
\hline Age & $\begin{array}{l}0.014 \\
(7.22)^{* * *}\end{array}$ & $\begin{array}{l}0.023 \\
(7.32)^{* * *}\end{array}$ & $\begin{array}{l}0.005 \\
(2.78)^{* * *}\end{array}$ \\
\hline Age squared & $\begin{array}{l}-0.019 \\
(7.29)^{* * *}\end{array}$ & $\begin{array}{l}-0.030 \\
(7.15)^{* * *}\end{array}$ & $\begin{array}{l}-0.008 \\
(3.12)^{* * *}\end{array}$ \\
\hline University education & $\begin{array}{l}-0.036 \\
(2.72)^{* * *}\end{array}$ & $\begin{array}{l}-0.069 \\
(3.34)^{* * *}\end{array}$ & $\begin{array}{l}-0.013 \\
(0.90)\end{array}$ \\
\hline Secondary education & $\begin{array}{l}-0.001 \\
(0.12)\end{array}$ & $\begin{array}{l}-0.003 \\
(0.15)\end{array}$ & $\begin{array}{l}-0.005 \\
(0.38)\end{array}$ \\
\hline English language knowledge & $\begin{array}{l}-0.005 \\
(0.54)\end{array}$ & $\begin{array}{l}0.011 \\
(0.55)\end{array}$ & $\begin{array}{l}-0.014 \\
(1.65)^{*}\end{array}$ \\
\hline No language knowledge & $\begin{array}{l}-0.058 \\
(6.87)^{* * *}\end{array}$ & $\begin{array}{l}-0.038 \\
(2.66)^{* * *}\end{array}$ & $\begin{array}{l}-0.066 \\
(7.31)^{* * *}\end{array}$ \\
\hline Household size & $\begin{array}{l}-0.007 \\
(2.24)^{* *}\end{array}$ & $\begin{array}{l}-0.003 \\
(0.52)\end{array}$ & $\begin{array}{l}-0.011 \\
(3.15)^{* * *}\end{array}$ \\
\hline Children (0-5) & $\begin{array}{l}-0.013 \\
(1.43)\end{array}$ & $\begin{array}{l}-0.004 \\
(0.30)\end{array}$ & $\begin{array}{l}-0.020 \\
(2.21)^{* *}\end{array}$ \\
\hline Elderly in the household & $\begin{array}{l}0.018 \\
(2.00)^{* *}\end{array}$ & $\begin{array}{l}0.011 \\
(0.74)\end{array}$ & $\begin{array}{l}0.020 \\
(1.98)^{* *}\end{array}$ \\
\hline Rural settlement & $\begin{array}{l}0.001 \\
(0.10)\end{array}$ & $\begin{array}{l}0.004 \\
(0.36)\end{array}$ & $\begin{array}{l}-0.003 \\
(0.37)\end{array}$ \\
\hline Belarus & $\begin{array}{l}0.004 \\
(0.37)\end{array}$ & $\begin{array}{l}0.020 \\
(1.00)\end{array}$ & $\begin{array}{l}-0.009 \\
(0.93)\end{array}$ \\
\hline Moldova & $\begin{array}{l}0.132 \\
(9.47)^{* * *}\end{array}$ & $\begin{array}{l}0.148 \\
(6.57)^{* * *}\end{array}$ & $\begin{array}{l}0.098 \\
(6.73) * * *\end{array}$ \\
\hline Georgia & $\begin{array}{l}-0.039 \\
(3.47)^{* * *}\end{array}$ & $\begin{array}{l}-0.043 \\
(2.15)^{* *}\end{array}$ & $\begin{array}{l}-0.029 \\
(2.94)^{* * *}\end{array}$ \\
\hline Armenia & $\begin{array}{l}0.062 \\
(4.94)^{* * *}\end{array}$ & $\begin{array}{l}0.139 \\
(6.40)^{* * *}\end{array}$ & $\begin{array}{l}-0.018 \\
(1.57)\end{array}$ \\
\hline $\begin{array}{l}\text { Observations } \\
\text { Pseudo R-squared }\end{array}$ & $\begin{array}{l}6082 \\
0.11\end{array}$ & $\begin{array}{l}2932 \\
0.11\end{array}$ & $\begin{array}{l}3150 \\
0.16\end{array}$ \\
\hline
\end{tabular}

Note: omitted categories are "Lower education”, "Urban settlement” and "Ukraine"

Robust z statistics in parentheses

* significant at $10 \%$; ** significant at 5\%; *** significant at $1 \%$

Source: INTAS; authors' calculations. 
Table 10: Probit Regressions of determinants of migration by countries; adults 16-65

\begin{tabular}{llllll}
\hline & $\begin{array}{c}(1) \\
\text { Armenia }\end{array}$ & $\begin{array}{c}(2) \\
\text { Belarus }\end{array}$ & $\begin{array}{c}(3) \\
\text { Georgia }\end{array}$ & $\begin{array}{c}(4) \\
\text { Moldova }\end{array}$ & $\begin{array}{c}(5) \\
\text { Ukraine }\end{array}$ \\
\hline \hline Female & -0.152 & -0.039 & -0.007 & -0.059 & -0.014 \\
Age & $(8.82)^{* * *}$ & $(3.37)^{* * *}$ & $(0.98)$ & $(2.64)^{* * *}$ & $(1.11)$ \\
& 0.007 & 0.005 & 0.002 & 0.051 & 0.013 \\
Age squared & $(2.25)^{* *}$ & $(1.26)$ & $(1.01)$ & $(7.19)^{* * *}$ & $(3.77)^{* * *}$ \\
& -0.009 & -0.011 & -0.003 & -0.069 & -0.017 \\
University education & $(2.25)^{* *}$ & $(1.78)^{*}$ & $(1.19)$ & $(7.05)^{* * *}$ & $(3.73)^{* * *}$ \\
& 0.019 & 0.071 & 0.524 & -0.132 & -0.026 \\
Secondary education & $(0.49)$ & $(1.19)$ & $(5.51)^{* * *}$ & $(3.86)^{* * *}$ & $(0.70)$ \\
& 0.037 & 0.059 & 0.603 & -0.049 & -0.003 \\
English language & $(1.27)$ & $(1.48)$ & $(6.66)^{* * *}$ & $(1.59)$ & $(0.09)$ \\
knowledge & -0.036 & 0.018 & 0.027 & -0.084 & -0.013 \\
No foreign language & $(1.12)$ & $(0.85)$ & $(2.05)^{* *}$ & $(2.31)^{* *}$ & $(0.76)$ \\
knowledge & 0.015 & -0.015 & -0.005 & -0.222 & -0.073 \\
Household size & $(0.60)$ & $(0.82)$ & $(0.49)$ & $(7.42)^{* * *}$ & $(4.80)^{* * *}$ \\
& 0.004 & -0.018 & -0.005 & -0.011 & -0.017 \\
Children (0-5) & $(0.77)$ & $(1.96)^{* *}$ & $(1.30)$ & $(0.88)$ & $(2.70)^{* * *}$ \\
& -0.031 & -0.008 & -0.003 & -0.002 & -0.013 \\
Elderly in the & $(2.14)^{* *}$ & $(0.48)$ & $(0.25)$ & $(0.06)$ & $(0.76)$ \\
household & 0.019 & 0.027 & -0.001 & 0.110 & 0.006 \\
Rural settlement & $(1.34)$ & $(1.12)$ & $(0.14)$ & $(2.32)^{* *}$ & $(0.39)$ \\
& -0.014 & 0.030 & 0.012 & -0.003 & -0.022 \\
\hline Observations & $(0.86)$ & $(1.96)^{*}$ & $(1.33)$ & $(0.13)$ & $(1.65)^{*}$ \\
Pseudo R-squared & 1291 & 1153 & 1302 & 1197 & 1139 \\
\hline \hline
\end{tabular}

Note: omitted categories are "Lower education" and "Urban settlement"

Robust z statistics in parentheses

* significant at 10\%; ** significant at 5\%; *** significant at $1 \%$

Source: INTAS; authors' calculations. 
Table 11: The impact of unemployment on the propensity to migrate

\begin{tabular}{|c|c|c|c|c|c|}
\hline & $\begin{array}{c}(1) \\
\text { Armenia } \\
\end{array}$ & $\begin{array}{c}(2) \\
\text { Belarus } \\
\end{array}$ & $\begin{array}{c}\text { (3) } \\
\text { Georgia }\end{array}$ & $\begin{array}{c}(4) \\
\text { Moldova } \\
\end{array}$ & $\begin{array}{c}\text { (5) } \\
\text { Ukraine }\end{array}$ \\
\hline \multicolumn{6}{|l|}{ Individual level regression } \\
\hline Individual unemployment & $\begin{array}{c}-0.026 * * \\
(0.012)\end{array}$ & $\begin{array}{c}0.145^{* * *} \\
(0.051)\end{array}$ & $\begin{array}{l}-0.010 \\
(0.008)\end{array}$ & $\begin{array}{c}0.016 \\
(0.029)\end{array}$ & $\begin{array}{c}0.068 * * \\
(0.029)\end{array}$ \\
\hline \multicolumn{6}{|l|}{ Household level regression } \\
\hline $\begin{array}{l}\text { Unemployment within } \\
\text { household }\end{array}$ & $\begin{array}{c}0.023^{* * *} \\
(0.006)\end{array}$ & $\begin{array}{l}0.046^{*} \\
(0.026)\end{array}$ & $\begin{array}{c}-0.004 * * \\
(0.002)\end{array}$ & $\begin{array}{c}0.035^{* *} \\
(0.017)\end{array}$ & $\begin{array}{c}0.090 * * * \\
(0.020)\end{array}$ \\
\hline \multicolumn{6}{|c|}{$\begin{array}{l}\text { Note: For a list of controls in the individual regression, see Table 9. For a list of controls in the individual regression, } \\
\text { see Table 12. Simple sizes for individual regression: Armenia (1291), Belarus (1153), Georgia (1302), Moldova (1197), } \\
\text { Ukraine (1139). Representatively weighted sample sizes for household regressions: Armenia (1911), Belarus (1424), } \\
\text { Georgia (1757), Moldova (1576), Ukraine (1495). } \\
\text { Robust standard errors in parentheses } \\
* * * \text { p }<0.01, * * p<0.05, * p<0.1 \\
\text { Source: INTAS: authors' calculations. }\end{array}$} \\
\hline
\end{tabular}


Table 12: Probit Regressions of determinants of poverty, household level; weighted by household size

\begin{tabular}{|c|c|c|c|c|}
\hline & $\begin{array}{c}\text { (1) } \\
\text { Constrained }\end{array}$ & $\begin{array}{c}(2) \\
\text { Constrained - } \\
\text { extended }\end{array}$ & $\begin{array}{c}\text { (3) } \\
\text { Food poor }\end{array}$ & $\begin{array}{c}\text { (4) } \\
\text { Food poor - } \\
\text { extended }\end{array}$ \\
\hline Migrant household & $\begin{array}{l}-0.049 \\
(3.58)^{* * *}\end{array}$ & $\begin{array}{l}-0.067 \\
(3.07)^{* * *}\end{array}$ & $\begin{array}{l}-0.003 \\
(0.37)\end{array}$ & $\begin{array}{l}-0.027 \\
(2.26)^{* *}\end{array}$ \\
\hline Female migrant household & & $\begin{array}{l}0.027 \\
(1.04)\end{array}$ & & $\begin{array}{l}0.044 \\
(2.56)^{* *}\end{array}$ \\
\hline Household size & $\begin{array}{l}0.017 \\
(3.60)^{* * *}\end{array}$ & $\begin{array}{l}0.017 \\
(3.54)^{* * *}\end{array}$ & $\begin{array}{l}0.003 \\
(0.99)\end{array}$ & $\begin{array}{l}0.002 \\
(0.88)\end{array}$ \\
\hline Female-headed household & $\begin{array}{l}0.034 \\
(2.96)^{* * *}\end{array}$ & $\begin{array}{l}0.028 \\
(2.11)^{* *}\end{array}$ & $\begin{array}{l}-0.010 \\
(1.40)\end{array}$ & $\begin{array}{l}-0.019 \\
(2.46)^{* *}\end{array}$ \\
\hline Avg. Household age & $\begin{array}{l}0.000 \\
(0.90)\end{array}$ & $\begin{array}{l}0.000 \\
(0.91)\end{array}$ & $\begin{array}{l}-0.000 \\
(0.50)\end{array}$ & $\begin{array}{l}-0.000 \\
(0.49)\end{array}$ \\
\hline Avg. Household schooling & $\begin{array}{l}-0.002 \\
(0.76)\end{array}$ & $\begin{array}{l}-0.002 \\
(0.78)\end{array}$ & $\begin{array}{l}-0.000 \\
(0.26)\end{array}$ & $\begin{array}{l}-0.001 \\
(0.36)\end{array}$ \\
\hline Share of women & $\begin{array}{l}-0.040 \\
(1.28)\end{array}$ & $\begin{array}{l}-0.040 \\
(1.30)\end{array}$ & $\begin{array}{l}-0.005 \\
(0.28)\end{array}$ & $\begin{array}{l}-0.006 \\
(0.29)\end{array}$ \\
\hline Share of children & $\begin{array}{l}0.011 \\
(0.21)\end{array}$ & $\begin{array}{l}0.010 \\
(0.21)\end{array}$ & $\begin{array}{l}-0.002 \\
(0.06)\end{array}$ & $\begin{array}{l}-0.002 \\
(0.08)\end{array}$ \\
\hline Share of elderly & $\begin{array}{l}-0.031 \\
(0.56)\end{array}$ & $\begin{array}{l}-0.030 \\
(0.54)\end{array}$ & $\begin{array}{l}0.041 \\
(1.20)\end{array}$ & $\begin{array}{l}0.043 \\
(1.26)\end{array}$ \\
\hline Rural settlement & $\begin{array}{l}-0.029 \\
(2.10)^{* *}\end{array}$ & $\begin{array}{l}-0.029 \\
(2.10)^{* *}\end{array}$ & $\begin{array}{l}0.007 \\
(0.90)\end{array}$ & $\begin{array}{l}0.007 \\
(0.85)\end{array}$ \\
\hline Regional centre & $\begin{array}{l}-0.127 \\
(7.23)^{* * *}\end{array}$ & $\begin{array}{l}-0.126 \\
(7.20)^{* * *}\end{array}$ & $\begin{array}{l}-0.041 \\
(3.93)^{* * *}\end{array}$ & $\begin{array}{l}-0.041 \\
(3.85)^{* * *}\end{array}$ \\
\hline Armenia & $\begin{array}{l}0.236 \\
(14.68)^{* * *}\end{array}$ & $\begin{array}{l}0.235 \\
(14.57) * * *\end{array}$ & $\begin{array}{l}0.215 \\
(15.05)^{* * *}\end{array}$ & $\begin{array}{l}0.212 \\
(14.87)^{* * *}\end{array}$ \\
\hline Belarus & $\begin{array}{l}-0.072 \\
(3.71)^{* * *}\end{array}$ & $\begin{array}{l}-0.073 \\
(3.73)^{* * *}\end{array}$ & $\begin{array}{l}-0.091 \\
(6.06)^{* * *}\end{array}$ & $\begin{array}{l}-0.092 \\
(6.08)^{* * *}\end{array}$ \\
\hline Georgia & $\begin{array}{l}0.233 \\
(13.58) * * *\end{array}$ & $\begin{array}{l}0.233 \\
(13.56)^{* * *}\end{array}$ & $\begin{array}{l}0.069 \\
(4.85)^{* * *}\end{array}$ & $\begin{array}{l}0.068 \\
(4.77)^{* * *}\end{array}$ \\
\hline Moldova & $\begin{array}{l}0.186 \\
(10.97)^{* * *}\end{array}$ & $\begin{array}{l}0.186 \\
(10.94)^{* * *}\end{array}$ & $\begin{array}{l}0.142 \\
(9.81)^{* * *}\end{array}$ & $\begin{array}{l}0.142 \\
(9.79)^{* * *}\end{array}$ \\
\hline Observations & 8149 & 8149 & 8149 & 8149 \\
\hline Pseudo R-squared & 0.09 & 0.09 & 0.12 & 0.12 \\
\hline
\end{tabular}

Note: omitted categories are "Lower education", "Urban settlement” and "Ukraine"

Robust $\mathrm{z}$ statistics in parentheses

* significant at $10 \%$; ** significant at $5 \%$; *** significant at $1 \%$

Source: INTAS; authors' calculations. 
Table 13: Poverty ratios and migration incidence 2006 by past migration experience

\begin{tabular}{llccc}
\hline & Outcomes & No migrant & $\begin{array}{c}\text { Migrant in } \\
\text { 2004 or 2005 }\end{array}$ & $\begin{array}{c}\text { Migrant in } \\
2004 \text { and 2005 }\end{array}$ \\
\hline \hline No migrant & $\begin{array}{l}\text { Share of constrained } \\
\text { households } \\
\text { Migration in 2006 }\end{array}$ & $66.2 \%$ & $* * *$ & insignificant \\
Migrant in 2004 or 2005 & $\begin{array}{l}\text { Share of constrained } \\
\text { households } \\
\text { Migration in 2006 }\end{array}$ & $52.9 \%$ & $* * *$ \\
Migrant in 2004 and 2005 & $\begin{array}{l}\text { Share of constrained } \\
\text { households } \\
\text { Migration in 2006 }\end{array}$ & $10.0 \%$ & $* * *$ \\
\hline \hline
\end{tabular}

Note: Analysis on the household level; shaded area shows level of significance for mean comparison tests between row and column category; ${ }^{* * *}$ indicates mean difference significant at $1 \%$ level.

Source: INTAS; authors' calculations. 
Table 14: Probit Regressions of determinants of household poverty; IV estimates

Dependent variable: Household is constrained

(1)

(2)

OLS

(3)

OLS

$$
\begin{array}{cc}
-0.064 * * * & -0.001 \\
(0.025) & (0.035)
\end{array}
$$

Migration 2004

$-0.126^{* *}$

(0.049)

Migration 2004*Female head

Migration

(instrumented)

$-0.163^{* *}$

(0.066)

Regional migration intensity early 2004

$$
\begin{array}{ccc}
-0.013^{* *} & -0.014^{* *} & -0.014^{* *} \\
(0.006) & (0.006) & (0.006)
\end{array}
$$

Unemployment within household

$\begin{array}{ccc}0.011 & 0.011 & 0.019 * \\ (0.011) & (0.011) & (0.011) \\ 0.032^{* * *} & 0.038^{* * *} & 0.024^{* *} \\ (0.011) & (0.011) & (0.011) \\ 0.015^{* * *} & 0.015^{* * *} & 0.015^{* * *} \\ (0.004) & (0.004) & (0.004)\end{array}$

Age of household head

$$
0.000
$$

0.000

0.000

(0.000)

(0.000)

(0.000)

Education of household head

$-0.001$

$-0.001$

$-0.002$

$(0.002)$

(0.002)

(0.002)

Share of women in household

$-0.032$

$-0.031$

$-0.029$

(0.029)

(0.029)

(0.029)

Share of elderly in household

$-0.037$

$-0.038$

$-0.022$

(0.052)

$(0.052)$

(0.053)

Rural settlement

0.002

0.003

$-0.025^{* *}$

(0.017)

Regional centre

$-0.122 * * *$

(0.017)

(0.016)

$-0.122 * * *$

(0.013)

Armenia

$0.223 * * *$

(0.016)

$-0.114^{* * *}$

Armenia

(0.020)

$0.219 * * *$

(0.016)

Belarus

$-0.077^{* * *}$

(0.020)

$0.235^{* * *}$

Georgia

(0.020)

$-0.077^{* * *}$

(0.017)

Moldova

$0.206 * * *$

(0.020)

$-0.086 * * *$

(0.020)

Constant

(0.032)

$0.203 * * *$

$0.250 * * *$

$0.209 * * *$

(0.032)

(0.019)

(0.020)

$0.209 * * *$

$0.193 * * *$

$0.542 * * *$

(0.020)

(0.018)

(0.052)

F-test of first stage

Observations

2003

$0.539 * * *$

$0.497 * * *$

R-squared

0.113

(0.052)

(0.045)

Note: Household sample weighted in order to yield representative sample.

Robust standard errors in parentheses

*** $\mathrm{p}<0.01, * * \mathrm{p}<0.05, * \mathrm{p}<0.1$

Source: INTAS; authors' calculations. 